\title{
Analisis kemampuan berpikir kreatif dan minat belajar siswa dalam mengerjakan soal open ended dengan pendekatan CTL
}

\author{
Puput Wahyu Hidayat *, Djamilah Bondan Widjajanti \\ Program Studi Pendidikan Matematika, Program Pascasarjana, Universitas Negeri Yogyakarta. \\ Jalan Colombo No. 1, Karangmalang, Yogyakarta 55281, Indonesia. \\ * Corresponding Author. E-mail: puputwahyuhidayat@gmail.com \\ Received: 8 September 2018; Revised: 17 September 2018; Accepted: 21 September 2018
}

\begin{abstract}
Abstrak
Penelitian ini bertujuan untuk menganalisis kategori dan aspek kemampuan berpikir kreatif dan minat belajar siswa, peningkatan minat belajar, dan menganalisis pembelajaran yang lebih baik antara pendekatan Contextual Teaching and Learning (CTL) dengan soal open ended dan pendekatan CTL ditinjau dari kemampuan berpikir kreatif dan minat belajar siswa SMP. Penelitian ini adalah penelitian eksperimen semu, dengan rancangan pretest-posttest non-equivalent group design. Populasi penelitian mencakup seluruh siswa kelas VIII SMP Negeri 1 Miri, Kabupaten Sragen, Jawa Tengah, Indonesia, dan diambil secara acak dua kelas sebagai sampel penelitian. Instrumen pengumpulan data menggunakan tes dan angket. Untuk menganalisis kategori dan aspek kemampuan berpikir kreatif dan minat belajar digunakan analisis descriptives statistic, untuk menganalisis peningkatan minat belajar digunakan uji $t$-Paired pada taraf signifikansi $5 \%$. Selanjutnya, untuk membandingkan pembelajaran yang lebih baik antara pendekatan CTL menggunakan soal open ended dengan pendekatan CTL, data dianalisis dengan menggunakan MANOVA yang kemudian dilanjutkan dengan uji $t$ independent untuk menentukan pendekatan yang lebih baik. Hasil penelitian menunjukkan bahwa kategori kemampuan berpikir kreatif pada kelas CTL dengan open ended berada pada kategori tinggi, pada kelas CTL berada pada kategori sedang, untuk kategori minat belajar, siswa di kedua kelas berada pada kategori tinggi, kategori aspek kemampuan berpikir kreatif untuk kedua kelas memiliki presentase tertinggi pada aspek kelancaran, minat belajar siswa untuk kedua kelas meningkat secara signifikan, dan pendekatan CTL menggunakan soal open ended lebih baik daripada pendekatan CTL ditinjau dari aspek kemampuan berpikir kreatif siswa, sedangkan pendekatan CTL menggunakan soal open ended tidak lebih baik daripada pendekatan CTL ditinjau dari minat belajar siswa.
\end{abstract}

Kata Kunci: Contextual Teaching and Learning, kemampuan berpikir kreatif, minat belajar

\section{An analysis of creative thinking ability and learning interest of students of junior high school in solving open ended problem with CTL approach}

\begin{abstract}
This research aimed to analyze the categories and aspects of creative thinking ability and in student learning interest, the increase of students learning interest, and the better learning between CTL approach using open ended questions with CTL approach in terms of the ability to think creatively and interest in learning of students of Junior High School. This research was a quasi-experimental research with pretest-posttest non-equivalent comparison-group design. The research population comprised all year VIII students of SMP Negeri 1 Miri, Sragen Regency, Indonesia. From the population, two classes were randomly selected as the research sample. The instruments used were in the form of creative thinking ability tests and questionnaires for students' interest in learning mathematics. To analyze the categories and aspects of creative thinking abilities and interest in learning, descriptives statistical analysis was used, to analyze the increase of students' interest, the data were analyzed using paired ttest at 5\% significance level. As for comparing better learning between CTL approach using open ended questions with CTL approach, the data were analyzed using MANOVA followed by t-test independent to determine which approach was better. The results showed that the category of creative thinking abilities in the classroom CTL using open ended questions in the high category, while in the CTL approach class was in middle category, for the category of interest in learning, either with CTL approach using open ended questions or as with the CTL approach, students were of the high category, categories of creative thinking abilities, for both classes have the highest percentage on the aspect of
\end{abstract}


smoothness, by providing CTL approach with open ended questions and CTL approach, students' interest increased significantly and CTL approach with open ended questions was better than CTL approach in terms of students' ability to think creatively, and CTL approach with open ended questions was not better than CTL approach in terms of student interest.

Keywords: Contextual Teaching and Learning approach, creative thinking ability, learning interest

How to Cite: Hidayat, P., \& Widjajanti, D. (2018). Analisis kemampuan berpikir kreatif dan minat belajar siswa dalam mengerjakan soal open ended dengan pendekatan CTL. Pythagoras: Jurnal Pendidikan Matematika, 13(1), 63-75. doi:http://dx.doi.org/10.21831/pg.v13i1.21167

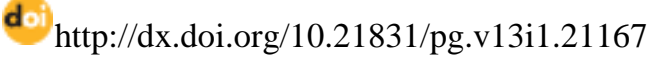

\section{PENDAHULUAN}

Pendidikan memegang peranan besar dalam kemajuan suatu bangsa. Hal ini disebabkan pendidikan akan membawa suatu bangsa untuk menjadi lebih maju dan lebih baik dari segala sisi kebutuhannya. Undang-undang Nomor 20 Tahun 2003 tentang Sistem Pendidikan Nasional, Pasal 3 menegaskan bahwa pendidikan nasional berfungsi mengembangkan kemampuan dan membentuk watak serta peradaban bangsa yang bermartabat dalam rangka mencerdaskan kehidupan bangsa, bertujuan untuk berkembangnya potensi peserta didik agar menjadi manusia yang beriman dan bertakwa kepada Tuhan Yang Maha Esa, berakhlak mulia, sehat, berilmu, cakap, kreatif, mandiri, dan menjadi warga negara yang demokratis serta bertanggung jawab.

Untuk mengembangkan mutu pendidikan, pendidik atau guru diharuskan untuk lebih pintar dalam mengelola kelas maupun melakukan kegiatan pembelajaran yang lainnya. Seperti yang tercantum dalam Peraturan Menteri Pendidikan dan Kebudayaan Tahun 2013 Nomor 65, disebutkan bahwa proses pembelajaran pada satuan pendidikan diselenggarakan secara interaktif, inspiratif, menyenangkan, menantang, memotivasi siswa untuk berpartisipasi aktif, serta memberikan ruang yang cukup bagi prakarsa, kreativitas, dan kemandirian sesuai dengan bakat, minat, dan perkembangan fisik serta psikologis siswa. Sehingga melalui kegiatan pembelajaran tersebut, siswa difasilitasi oleh guru untuk terlibat secara aktif mengembangkan potensi dirinya. Dengan pengalaman yang dimiliki oleh guru, siswa dapat melakukan kegiatan yang memungkinkan untuk dikembangkan potensi yang dimiliki menjadi kompetensi yang ditetapkan dalam kurikulum.

Menurut Fauzan (2002, p.34), para guru dan siswa-siswa menyukai materi pembelajaran dengan pendekatan realistik, konstektual dan terbuka. Materi dalam buku paket harus dipilih dan disesuaikan dengan lingkungan yang berkaitan dengan kehidupan sehari-hari (kontekstual). Dengan menggunakan materi realistik, kontekstual, dan terbuka di kelas, kegiatan pembelajaran akan menjadi lebih baik, siswa lebih aktif dan kreatif, dan guru tidak lagi menggunakan 'chalk and talk' serta peran guru dari yang awalnya melakukan proses belajar mengajar dengan cara menulis dan menyampaikan materi beralih fungsi menjadi pembimbing dan narasumber.

Pada saat ini, kegiatan pembelajaran di sekolah belum sesuai dengan harapan, termasuk pembelajaran matematika. Pembelajaran yang dilakukan cenderung berpusat pada guru, guru menyampaikan dan siswa menerima. Guru menyampaikan pelajaran dengan menggunakan metode ceramah atau ekspositori, sementara siswa mencatatnya pada buku catatan. Dengan pembelajaran matematika yang seperti ini, siswa akan belajar matematika hanya dengan cara menghafal dan sekedar mengingat rumus. Padahal matematika lebih bersifat abstrak. Sehingga dengan pembelajaran yang seperti itu, menghafal dan mengingat sesuatu yang abstrak, menjadikan matematika akan terkesan lebih sulit dan membosankan serta menjadikan kemampuan berpikir kreatif siswa belajar matematika siswa pada umumnya kurang terasah, sehingga cenderung rendah. Padahal dalam belajar matematika siswa akan lebih memaknai matematika jika anak mengalami apa yang dipelajari.

Berpikir kreatif dapat diartikan sebagai suatu kegiatan mental yang digunakan seorang untuk membangun ide atau gagasan yang baru (Meador, 1997, p.2; Siswono, 2007, p.2; Johnson, 2011, p.214; Maite \& Laura, 2011, p.609). Kemampuan berpikir kreatif matematis merupakan suatu kemampuan yang digunakan ketika seseorang memunculkan suatu ide baru yang mudah dan fleksibel untuk menyelesaikan masalah matematika yang ditandai dengan terlihatnya ketrampilan siswa dalam berpikir lancar, luwes, baru dan terperinci (Guilford dalam Park, 2004, p.15; Kruse, 2009, p.5; Dwijanto, 2007, 
pp.31-32; Torrance dalam Alter, 2010, p.5); Mahmudi, 2010, p.5).

Kemampuan berpikir kreatif merupakan salah satu proses pemikiran tingkat tinggi yang jarang dilatih. Hal ini tampak dalam bidang pendidikan terutama dalam mata pelajaran matematika yang menekankan lebih pada hafalan dan konsep penalaran serta mencari jawaban yang benar terhadap soal-soal matematika. Seperti yang dinyatakan oleh psikolog asal Amerika, Joy Paul Guilford (Munandar, 2009: p7), bahwa keluhan yang paling banyak ditemukan mengenai lulusan perguruan tinggi ialah bahwa siswa cukup mampu melakukan tugas-tugas yang diberikan dengan teknik-teknik yang diajarkan, namun tidak berdaya jika dituntut memecahkan masalah yang memerlukan cara-cara yang baru.

Oleh karena itu, selayaknya bidang pendidikan memberi perhatian lebih mengenai berpikir kreatif dan memiliki kesadaran akan pentingnya berpikir kreatif bagi ilmu pengetahuan. Walaupun terkait dengan kendala konseptual, seperti yang dinyatakan Munandar (2009, p.7) bahwa kendala konseptual lainnya terhadap 'gerakan kreativitas' terletak pada alat-alat ukur (tes) yang biasanya dipakai di sekolah-sekolah, yaitu tes intelegensi tradisional yang mengukur kemampuan siswa untuk belajar, dan tes prestasi belajar untuk menilai kemajuan siswa selama program pendidikan.

Selain hal itu, potensi yang menjadi sasaran pengembangan proses pendidikan melalui penciptaan suasana dan proses pembelajaran adalah berpikir siswa. Dalam kegiatan pembelajaran matematika, siswa tidak hanya dihadapkan oleh pengetahuan membutuhkan pemahaman konsep, tetapi juga bagaimana membangun cara berpikir siswa, seperti berpikir kritis dan kreatif. Dalam hal ini, salah satunya adalah dengan memberikan soal open ended, untuk mengasah kemampuan berpikir kreatif siswa Becker dan Shimada (2005, p.3). Soal open ended adalah soal yang mempunyai banyak solusi atau strategi penyelesaian (Hancock, 1995, pp.183-496; Takahashi, 2008, p.2; Syaban, 2011, p.1).

Dengan memberikan soal open ended kepada siswa, maka pembelajaran tersebut dapat membangun kegiatan interaktif antara matematika dan siswa sehingga mengundang siswa untuk menjawab permasalahan melalui berbagai strategi. Berpikir kreatif siswa dapat diketahui dengan memberikan soal matematika dalam bentuk open ended, yaitu pertanyaan yang jawabannya dapat lebih dari satu dan tidak bisa diperkirakan sebelumnya. Karena dengan diberikannya soal dalam bentuk open ended akan menuntut siswa untuk menduga, membuat hipotesis, mengecek benar tidaknya hipotesis, meninjau penyelesaian secara menyeluruh dan mengambil kesimpulan.

Dengan menerapkan soal dalam bentuk open ended, maka dapat mengembangkan kemampuan berpikir kreatif siswa. Soal open ended dapat mengarahkan siswa dalam menjawab dengan banyak cara sehingga merangsang kemampuan intelektual dan pengalaman berpikir kreatif siswa. Keadaan ini akan membiasakan siswa berpikir dan bertindak secara kreatif pada diri siswa yang sangat diperlukan untuk menghadapi kehidupan dan melanjutkan pendidikan ke jenjang yang lebih tinggi. Dengan diberikannya soal open ended ke siswa, kemampuan berpikir kreatif siswa dapat diukur sesuai dengan indikatornya, yaitu berpikir lancar, luwes, merinci, dan orisinil (Kruse, 2009, p.5; Mahmudi, 2010, p.5).

Menurut Pehkonen (1997, p.6), jenis permasalahan yang digolongkan dalam open ended adalah investigasi, problem posing (menemukan atau merumuskan masalah), dan masalah dasar (masalah yang dihubungkan dengan kontekstual). Dengan adanya permasalahan dalam bentuk open ended tersebut, salah satunya adalah masalah yang berhubungan dengan kontekstual. Dengan memberikan permasalahan yang berhubungan dengan kontekstual dalam pembelajaran, akan memberikan pengaruh kepada siswa untuk belajar lebih baik, karena apa yang dipelajari terkait dengan apa yang telah diketahui dan dengan peristiwa yang akan terjadi di sekelilingnya.

Saat ini, pembelajaran kontekstual telah berkembang sebagai pendekatan pembelajaran di berbagai negara, termasuk di Indonesia. Dengan pendekatan kontekstual, maka matematika harus dikaitkan dengan kehidupan nyata siswa, dan guru membantu untuk mengaitkan materi pelajaran dengan kehidupan nyata dan menjadikan siswa semakin termotivasi dan berminat dalam melakukan kegiatan pembelajaran matematika di sekolah. Karena pendekatan dalam pembelajaran pada hakikatnya merupakan sarana untuk mencapai tujuan pembelajaran serta dapat meningkatkan aktivitas belajar yang dilakukan guru dan siswa. Dan salah satu pendekatan pembelajaran tersebut yang memberikan peluang bagi siswa untuk meningkatkan minat belajar dan kemampuan berpikir kreatif siswa adalah pendekatan contextual teaching and learning (CTL) dengan memberikan soal dalam bentuk open ended.

Pembelajaran dengan pendekatan CTL merupakan konsep pembelajaran yang menekankan pada keterkaitan antara materi pembelajaran 
dengan dunia kehidupan siswa secara nyata, sehingga siswa mampu menghubungkan dan menerapkan kompetensi hasil belajar dalam kehidupan sehari-hari (Zulkarnain, Kamariah, \& Kamaruddin, 2009, p.170; Syaefudin, 2009, p.165; Narohita, 2010, p.1439; Johnson, 2014, p.25; Hosnan, 2014, p.268).

Pendekatan CTL, dijadikan alternatif strategi belajar yang lebih memberdayakan siswa (Narendrati, 2017). Pendekatan CTL merupakan konsep belajar yang membantu guru mengaitkan antara materi yang diajarkan dengan situasi dunia nyata siswa dan mendorong siswa membuat hubungan antara pengetahuan yang dimiliki dengan penerapannya dalam kehidupan mereka sebagai anggota keluarga dan masyarakat. Dengan konsep itu, hasil pembelajaran diharapkan lebih bermakna bagi siswa dan mampu meningkatkan minat dalam belajar, sehingga memicu keberhasilan dalam kegiatan pembelajaran matematika.

Pada umumnya kemampuan berpikir kreatif siswa sangat berbeda setiap aspeknya, seperti kelancaran, keluwesan, keaslian dan keterperinciannya. Dan kebanyakan penelitian yang dilakukan adalah secara umum mengetahui tingkat kemampuan berpikir kreatif siswa. Akan lebih baik jika penelitian dilakukan dengan mengetahui secara terperinci atau mendalam aspek manakah yang terlihat meningkat setelah diberikan suatu strategii atau pendekatan pembelajaran, seperti menggunakan pendekatan CTL dengan memberikan soal-soal open ended.

Berdasarkan hasil wawancara peneliti dengan guru matematika di kelas VIII SMP Negeri 1 Miri, Kabupaten Sragen, peneliti memperoleh beberapa informasi seperti dalam mengerjakan soal matematika siswa mengalami kesulitan, siswa kurang aktif dalam kegiatan tanya jawab, padahal guru sudah memberi kesempatan untuk bertanya, soal yang diberikan adalah soal-soal dalam buku paket dan LKS, guru jarang memberikan soal dalam bentuk open ended. Pada saat pembelajaran berlangsung pun kebanyakan siswa malah melakukan pekerjaan lainnya, siswa kurang memperhatikan guru, siswa bermain sendiri dan bercanda dengan teman yang lainnya. Itu bisa disebabkan karena matematika sulit bagi mereka, sehinga hanya satu dua orang siswa saja yang memperhatikan guru saat memberikan penjelasan.

Selain faktor pendekatan pembelajaran dan faktor kognitif siswa, faktor afektif dari dalam diri siswa yang juga memiliki peran besar dalam keberhasilan proses belajar matematika adalah faktor minat belajar. Minat merupakan salah satu faktor yang kuat dalam menentukan keberhasilan seseorang (Gable, 1986, p.9; Singer, 1987, p.78). Oleh karena itu agar berhasil dalam setiap usaha seseorang harus memupuk minat terhadap apa yang diinginkan. Didasari minat yang tinggi, seseorang akan berusaha untuk memperoleh hasil yang memuaskan walaupun banyak hambatan.

Minat merupakan kecenderungan seseorang yang sifatnya aktif yang senantiasa berhubungan dengan kesadaran, perhatian, kemauan, dan kesenangan atau perasaan senang terhadap suatu obyek yang ada sangkut paut dengan dirinya (Winkel, 2004, p.105; Safari, 2005, p.111; Slameto, 2010, p.180). Sehingga minat belajar siswa dapat diartikan sebagai suatu keadaan siswa yang dapat menumbuhkan rasa suka dan dapat membangkitkan semangat diri dalam melakukan suatu kegiatan yang dapat diukur melalui rasa suka, tertarik, memiliki perhatian dan keterlibatan dalam mengikuti proses pembelajaran.

Berdasarkan hasil observasi awal pembelajaran matematika yang berlangsung, peneliti menemukan kurangnya minat belajar matematika siswa. Beberapa indikasinya adalah siswa kurang aktif ketika melakukan kegiatan pelajaran matematika, siswa hanya mendengarkan penjelasan guru saja, sikap siswa yang terkesan malasmalasan dalam menerima pelajaran matematika, siswa terlihat ramai, siswa berbicara dengan temannya ketika pelajaran matematika berlangsung, siswa malu untuk bertanya kepada guru jika mengalami kesulitan, serta tidak terlihat adanya diskusi sehingga tidak ada kerja sama ketika pembelajaran matematika berlangsung.

Secara umum jika dilihat dari karakteristik siswa itu sendiri, siswa SMP berada pada masa puber yaitu peralihan dari masa anak-anak menuju masa remaja yang membutuhkan sesuatu yang dapat menarik perhatian, rasa keingintahuan, membangkitkan semangat, ataupun sesuatu yang berbeda dari yang selama ini didapatkan ketika pelajaran matematika. Proses pembelajaran khususnya untuk pembelajaran matematika akan lebih menyenangkan, tidak membosankan dan lebih mudah dipahami siswa jika menggunakan suatu pendekatan pembelajaran yang tepat yaitu pendekatan yang dapat menumbuhkan minat belajar matematika, salah satunya adalah dengan menggunakan pendekatan CTL.

Sementara itu, pada saat guru memberikan latihan soal, terlihat siswa kurang aktif dalam mencari penyelesaian soal tersebut. Hanya beberapa siswa yang mengerjakannya sehingga guru berulang kali memberi perintah kepada siswa, 
mungkin karena soal yang diberikan merupakan soal dari dalam buku paket, sehingga siswa kurang berminat mengerjakan soal tersebut. Sehingga dengan adanya masalah tersebut, sebagai guru harus pintar menggunakan taktiknya agar pembelajaran yang berlangsung dapat mengembangkan cara berpikir kreatif serta meningkatkan minat belajar siswa, yaitu dengan memberikan inovasi pembelajaran yang menjadikan pembelajaran menyenangkan dan bermakna bagi siswa.

Dengan adanya strategi pembelajaran matematika dengan pendekatan CTL, dalam penelitian ini, peneliti memilih materi pelajaran sistem persamaan linear dua variabel (SPLDV). Karena dalam materi ini karakteristiknya adalah berhubungan dengan kehidupan sehari-hari. Materi di kaitkan dengan kehidupan sehari-hari siswa, sehingga siswa akan merasa pembelajaran matematika yang diperolehnya memiliki makna, hal ini akan menjadikan minat belajar matematika dapat meningkat, selain itu dengan memberikan dalam bentuk permasalahan open ended, diharapkan kemampuan berpikir kreatif siswa juga dapat meningkat dan pembelajaran menjadi lebih baik.

Berdasarkan latar belakang masalah berikut kajian teori yang telah dikemukakan sebelumnya, maka penelitian ini bertujuan untuk menganalisis kategori dan aspek kemampuan berpikir kreatif dan minat belajar siswa, peningkatan minat belajar, dan menganalisis pembelajaran yang lebih baik antara pendekatan Contextual Teaching and Lerning (CTL) dengan soal open ended dan pendekatan CTL ditinjau dari kemampuan berpikir kreatif dan minat belajar siswa SMP.

\section{METODE}

Populasi pada penelitian ini yaitu seluruh siswa kelas VIII SMP Negeri 1 Miri Kabupaten Sragen tahun pelajaran 2014/2015 yang berjumlah 250 siswa yang terdiri atas 8 kelas. Sesuai dengan desain penelitian, dari 8 kelas dipilih secara acak (diundi) 2 kelas untuk menjadi sampel penelitian. Selanjutnya, dua kelas yang terpilih diundi lagi secara acak untuk diberikan perlakuan dengan masing-masing kelas secara berturut-turut diberi perlakuan pembelajaran dengan pendekatan contextual teaching and learning dengan soal open ended dan pendekatan contextual teaching and learning. Berdasarkan penentuan secara acak, diperoleh kelas VIIIE dengan menggunakan pendekatan contextual teaching and learning dengan soal open ended dan kelas VIIIF menggunakan pendekatan CTL, serta mengum- pulkan data setelah diberikan perlakuan pada masing-masing kelas eksperimen, yaitu dengan memberikan posttest kemampun berpikir kreatif dan angket minat belajar siswa. Berdasarkan hasil uji coba instrumen tes kemampuan berpikir kreatif matematis dan angket minat belajar matematika diperoleh koefisien reliabilitas berturutturut sebesar 0,728 dan 0,898. Reynolds, Livingston \& Willson (2010, p.108) menjelaskan tentang salah satu panduan umum untuk mengevaluasi koefisien reliabilitas yaitu bahwa estimasi reliabilitas yang diharapkan paling sedikit adalah 0,70 .

Teknik analisis data yang digunakan dalam penelitian ini adalah teknik parametrik dengan perhitungan manual dan menggunakan bantuan program software. Data yang dianalisis adalah data pretest dan posttest pada aspek kemampuan berpikir kreatif matematis dan minat belajar siswa. Data pretest digunakan untuk mengetahui kondisi awal siswa sebelum diberikan perlakuan dan data posttest digunakan untuk mendeskripsikan kemampuan berpikir kreatif matematis dan minat belajar siswa serta untuk melihat pendekatan mana yang lebih baik antara pendekatan pembelajaran CTL dengan soal open ended dengan pendekatan pembelajaran CTL setelah diberikan perlakuan.

Deskripsi data dilakukan dengan analisis deskriptif. Data yang dideskripsikan merupakan data yang diperoleh dari pengukuram pada variabel-variabel penelitian (variabel terikat) yaitu kemampuan berpikir kreatif dan minat belajar matematika siswa. Selain mengkategorikan tingkat berpikir siswa, data juga dianalisis sesuai dengan indikator kemampuan berpikir kreatif siswa. Siswa tersebut berada pada aspek kelancaran, keterperincian, keaslian, atau keluwesan. Setelah mengetahui tingkatan kategori kemampuan berpikir kreatif matematis siswa, pembahasan selanjutnya adalah menentukan berada di aspek kelancaran, keluwesan, keterperincian, atau pada aspek keaslian untuk kemampuan berpikir kreatif matematika siswa.

Untuk menganalisis peningkatan minat belajar digunakan uji t-paired terhadap rata-rata skor postttest dengan pretest untuk kedua kelas, yang bertujuan mengetahui apakah terjadi peningkatan minat belajar siswa setelah diberikan pendekatan CTL dengan soal open ended dan setelah diberikan pendekatan CTL dalam pembelajaran matematika. Sementara itu digunakan uji komparasi untuk mengetahui pembelajaran dengan pendekatan mana yang lebih baik antara pendekatan CTL dengan soal open ended dengan 
pendekatan CTL ditinjau dari kemampuan berpikir kreatif dan minat belajar siswa. Adapun syarat yang harus dipenuhi adalah menganalisis sebelum perlakuan terlebih dahulu, kemudian dilanjutkan untuk data setelah perlakuan.

Analisis sebelum perlakuan dimaksudkan untuk menguji kesamaan kondisi awal siswa ditinjau dari kemampuan berpikir kratif dan minat belajar matematika siswa. Hasil uji ini menentukan jenis uji yang akan digunakan untuk menguji hipotesis penelitian selanjutnya. Data-data yang diperoleh selama penelitian berlangsung harus memenuhi uji asumsi terlebih dahulu sebelum dilakukan proses analisis. Uji asumsi yang harus dipenuhi adalah uji normalitas dengan menggunakan uji Kolmogorov Smirnov. Selain itu, homogenitas kedua kelompok diuji dengan menggunakan uji Box-M. Kriteria keputusan untuk normalitas dan homogenitas yaitu jika nilai signifikansi yang diperoleh lebih dari 0,05; maka data berasal dari populasi yang berdistribusi normal dan matriks kovarians kedua populasi tersebut homogen.

Setelah diberikan perlakuan, sebelum dianalisis terlebih dahulu dilakukan uji two-group MANOVA untuk menguji ada tidaknya perbedaan diantara kedua pendekatan pembelajaran ditinjau dari kemampuan berpikir kretif dan minat belajar matematika siswa. Adapun kriteria dan syarat pengambilan keputusan yang digunakan sama dengan yang digunakan pada data sebelum perlakuan, yaitu menentukan normalitas dan homegenitas data terlebih dahulu.

Berdasarkan hasil uji hipotesis tahap pertama, apabila hasil uji two-group MANOVA terhadap nilai posttest menunjukkan terdapat perbedaan rata-rata dari kedua pendekatan pembelajaran ditinjau kemampuan berpikir kreatif dan minat belajar matematika siswa, maka dilakukan uji lanjut untuk menentukan pendekatan mana yang lebih baik. Pengujian hipotesis tersebut menggunakan uji-t independen dengan taraf signifikansi $\alpha=0,05$. Dengan kriteria pengujian jika $t_{h i t} \geq t_{(\alpha ; n 1+n 2-2)}$ maka $\mathrm{H}_{0}$ di tolak. Rumus yang digunakan adalah sebagai berikut:

$$
t=\frac{\bar{y}_{1}-\bar{y}_{2}}{\sqrt{\frac{\left(n_{1}-1\right) s_{1}^{2}+\left(n_{2}-1\right) s_{2}^{2}}{n_{1}+n_{2}-2}\left(\frac{1}{n_{1}}+\frac{1}{n_{2}}\right)}}
$$

Dengan $\bar{y}_{1}=$ nilai rata-rata sampel dengan CTL dengan soal open ended; $\bar{y}_{2}=$ nilai rata-rata sam-pel dengan CTL; $s_{1}^{2}=$ variansi sampel kelompok CTL dengan soal open ended; $s_{2}^{2}=$ variansi sampel kelompok CTL; $n_{1}=$ banyaknya anggota sampel kelompok CTL dengan soal open ended;

$n_{2}=$ banyaknya anggota sampel kelompok CTL. (Walpole, 1995, p.305; Stevens, 2009, p.147).

\section{HASIL DAN PEMBAHASAN}

\section{Analisis Multivariat}

Pada penelitian ini, semua asumsi telah terpenuhi, dimana data yang diperoleh berdistribusi normal multivariat, serta matriks kovarians kedua populasi homogen. Selanjutnya untuk mengetahui apakah terdapat perbedaan perlakuan pada kedua kelas ditinjau dari kemampuan berpikir kreatif dan minat belajar siswa secara simultan, maka dilakukan uji hipotesis menggunakan analisis MANOVA dua kelompok pada taraf signifikan $95 \%(\alpha=0,05)$. Berdasarkan hasil analisis tersebut, diperoleh $\mathrm{F}=16,623$ dengan nilai Sig. $=$ 0,000 . Berdasarkan hasil tersebut, diperoleh informasi bahwa nilai signifikansi $F$ lebih kecil dari 0,05 . Artinya, terdapat perbedaan antara kelas yang menggunakan pendekatan CTL dengan soal open ended dengan kelas yang menggunakan pendekatan CT $L$ ditinjau dari aspek kemampuan berpikir kreatif dan minat belajar siswa.

Selanjutnya, setelah diketahui bahwa terdapat perbedaan antara kedua pendekatan tersebut, maka dilakukan uji hipotesis mengenai pendekatan mana yang lebih baik ditinjau dari kemampuan berpikir kreatif dan minat belajar matematika siswa. Berikut penjelasan rinci untuk masing-masing aspek tersebut.

\section{Kemampuan Berpikir Kreatif}

Adapun hipotesis yang diuji adalah sebagai berikut:

$\mathrm{H}_{0}: \mu_{11} \leq \mu_{21}$ (Kemampuan berpikir kreatif siswa pada pembelajaran CTL dengan soal openended tidak lebih baik daripada pembelajaran CTL).

$\mathrm{H}_{\mathrm{a}}: \mu_{11}>\mu_{21}$ (Kemampuan berpikir kreatif siswa pada pembelajaran CTL dengan soal openended lebih baik daripada pembelajaran CTL).

Perhitungan dilakukan secara manual dengan bantuan Microsoft office excel, sehingga diperoleh nilai hasil seperti pada Tabel 1.

\section{Tabel 1. Hasil Uji independent t test KBKM}

\begin{tabular}{ccc}
\hline $\boldsymbol{t}$-hitung & $\boldsymbol{t}_{(\mathbf{0}, \mathbf{0 5} ; \mathbf{6 3})}$ & Keputusan \\
\hline 5,514 & 1,998 & $\mathrm{H}_{0}$ ditolak \\
\hline
\end{tabular}


Berdasarkan Tabel 1, diperoleh informasi bahwa nilai $t$-hitung $>t_{(0,05 ; 63)}(5,514>1,998)$, berarti $\mathrm{H}_{0}$ ditolak. Hal ini menunjukkan bahwa pendekatan CTL dengan soal open ended lebih baik daripada pendekatan CTL ditinjau dari kemampuan berpikir kreatif siswa.

\section{Minat Belajar Matematika}

Adapun hipotesis yang diuji adalah sebagai berikut:

$\mathrm{H}_{0}: \mu_{12} \leq \mu_{22}$ (Minat belajar siswa pada pembelajaran CTL dengan soal open-ended tidak lebih baik daripada pembelajaran CTL)

$\mathrm{H}_{\mathrm{a}}: \quad \mu_{12}>\mu_{22}$ (Minat belajar siswa pada pembelajaran CTL dengan soal open-ended lebih baik daripada pembelajaran CTL)

Perhitungan dilakukan manual dengan bantuan Microsoft office excel, diperoleh nilai $t$ hitung seperti pada Tabel 2.

Tabel 2. Hasil Uji independent t test Minat Belajar Matematika

\begin{tabular}{ccc}
\hline $\boldsymbol{t}$-hitung & $\boldsymbol{t}_{(\mathbf{0}, \mathbf{0 5} ; \mathbf{6 3})}$ & Keputusan \\
\hline 0,957 & 1,998 & $\mathrm{H}_{0}$ diterima \\
\hline
\end{tabular}

Berdasarkan Tabel 2, diperoleh informasi bahwa nilai $t$-hitung $<t_{(0,05 ; 63)}(0,957<1,998)$, berarti $\mathrm{H}_{03}$ diterima. Hal ini menunjukkan bahwa pendekatan CTL lebih baik daripada pendekatan CTL dengan soal open ended ditinjau dari aspek minat belajar matematika siswa.

\section{Analisis Kategori Kemampuan Berpikir Kreatif Matematis (KBKM)}

Sebelum melakukan pembahasan terhadap hasil penelitian yang telah dikemukakan, terlebih dahulu dikemukakan kategori yang digunakan untuk menentukan kualitas kemampuan siswa adalah kemampuan berpikir kreatif matematis siswa. Penentuan kategori didasarkan pada ratarata skor yang diperoleh. Kemampuan berpikir kreatif matematis siswa di bagi menjadi lima kategori, yaitu sangat tinggi, tinggi, sedang, rendah dan sangat rendah.

Data diperoleh dari instrumen yang berbentuk tes uraian selanjutnya data dianalisis dengan statistik deskriptif. Kemudian tingkat berpikir kreatif tersebut ditentukan menggunakan kriteria hasil pengukuran dengan menentukan rata-rata ideal ( $\overline{x i}$ ) dan simpangan baku ideal (Sbi). Setelah diperoleh data secara kuantitatif, maka peneliti menganalisis data tersebut sesuai kriteria yang dicapai oleh siswa Kelas VIII SMP Negeri 1 Miri dan mengkategorikan ke dalam tingkat berpikir sangat tinggi, tinggi, sedang, rendah atau sangat rendah. Data sebelum perlakuan pembelajaran pada kelas CTL dengan soal open ended sebagian besar siswa memiliki KBKM pada kategori rendah, yaitu sebanyak 20 orang $(58,8 \%), 13$ orang $(38,2 \%)$ memiliki KBKM kategori sedang, dan hanya 1 orang $(2,9 \%)$ yang memiliki kemampuan berpikir kreatif matematis siswa dalam kategori sangat rendah, dan tidak satu orang siswa pun yang berada pada kategori tinggi dan sangat tinggi.

Setelah mendapatkan pembelajaran pendekatan CTL dengan soal open ended, tidak terdapat lagi siswa yang tingkat KBKM pada kategori sangat rendah dan rendah. Terlihat ada 1 orang $(2,9 \%)$ yang memiliki KBKM pada kategori sangat tinggi, 18 orang $(52,9)$ pada kategori tinggi, dan 15 orang $(44,1 \%)$ pada kategori sedang. Sehingga dapat disimpulkan bahwa dengan memberikan pendekatan CTL dengan soal open ended, kemampuan berpikir kreatif siswa persentase terbesar berada pada kategori tinggi. Hal ini sesuai dengan pendapat Takashi $(2008$, p.2) tentang manfaat penggunaan soal open ended. Dengan memberikan soal open ended kepada siswa, maka siswa akan lebih aktif dalam mengekspresikan ide, mempunyai kesempatan yang lebih dalam menggunakan pengetahuannya, serta siswa memiliki pengalaman yang kaya dalam proses menemukan ide dari siswa yang lain. Sehingga dengan memberikan soal open ended dalam pembelajaran CTL, kemampuan berpikir kreatif siswa dapat terasah dan cenderung meningkat menjadi tinggi. Hal ini juga sejalan dengan hasil penelitian Fadilah (2014) yang menyimpulkan bahwa kemampuan berpikir kreatif siswa dalam proses belajar biologi Kelas XI IPA SMA Negeri 5 Kota Jambi termasuk tinggi.

Untuk kelas dengan pendekatan CTL, sebelum perlakuan sebagian besar siswa memiliki kemampuan berpikir kreatif matematis pada kategori rendah, yaitu sebanyak 23 orang $(74,2 \%)$, memiliki kemampuan yang sedang sebanyak 5 orang $(16,1 \%)$, dan terdapat 3 orang yang memiliki kemampuan berpikir kreatif siswa sangat rendah yaitu $9,7 \%$. Setelah perlakuan di kelas eksperimen kedua, dengan menggunakan pendekatan CTL, siswa yang memiliki KBKM kategori tinggi menjadi 4 orang $(12,9) \%$, dan masih ada yang memiliki KBKM pada kategori rendah sebanyak 2 orang $(6,5 \%)$, dan yang terbanyak adalah pada kategori sedang, yaitu 25 orang atau $80,6 \%$, serta tidak ada satupun orang siswa yang berada pada kategori sangat rendah ataupun sangat tinggi. Sehingga untuk kelas CTL siswa 
juga sebagian besar memiliki kemampuan berpikir kreatif pada kategori sedang. Hal ini sesuai dengan pendapat Munandar (2009, p.7) yang menyatakan bahwa kendala konseptual terhadap gerakan kreativitas terletak pada alat ukur yang biasa dipakai oleh sekolah, yaitu tes intelegensi tradisional yang mengukur kemampuan siswa untuk belajar. Dengan tidak diberikan soal dalam bentuk open ended, menjadikan kemampuan berpikir kreatif siswa kurang terasah, sehingga pada pendekatan CTL tanpa menggunakan soal open ended, kemampuan berpikir kreatif matematis siswa hanya berada pada kategori sedang.

Berdasarkan data-data yang telah dianalisis, maka dapat disimpulkan bahwa dengan menggunakan pendekatan CTL baik dengan soalsoal open ended maupun tidak, ternyata mampu meningkatkan kemampuan berpikir kreatif siswa. Namun yang lebih dominan adalah pada pembelajaran dengan pendekatan CTL dengan memberikan soal open ended, terlihat dari persentase terbanyak setelah diberikan perlakuan yaitu lebih dari setengah siswa yang memiliki tingkat kemampuan pada kategori tinggi.

\section{Analisis Kategori Minat Belajar Siswa}

Selain mendeskripsikan kemampuan berpikir kreatif siswa, peneliti juga mendeskripsikan data tentang minat belajar matematika siswa yang diperoleh dari instrumen yang berbentuk checklist dalam skala Likert, data tersebut dianalisis dengan statistik deskriptif. Analisis deskriptif yang dilakukan hanya untuk memperoleh skor minat belajar matematika siswa. Selanjutnya, digolongkan berdasarkan skor baku, penyekoran angket minat belajar dalam penelitian disesuaikan dengan jumlah butir pernyataan angket minat. Sehingga dengan 30 butir pernyataan yang ada dalam angket, dapat ditentukan skor terendah dan tertingginya, maka rentang penyekoran angket minat memiliki rentang antara 30 sampai dengan 150.

Setelah diperoleh data secara kuantitatif, maka peneliti menganalisis data tersebut sama seperti analisis data terhadap kategori berpikir kreatif matematis siswa, yaitu sesuai kriteria yang dicapai oleh siswa Kelas VIII SMP Negeri 1 Miri dan mengkategorikan ke dalam tingkat sangat tinggi, tinggi, sedang, rendah atau sangat rendah. Pada penelitian ini, diketahui bahwa sebelum perlakuan pembelajaran pada kelas CTL dengan soal open ended sebagian besar siswa memiliki minat belajar pada kategori sedang, yaitu sebanyak 22 orang $(64,7 \%), 5$ orang $(14,7 \%)$ memiliki minat belajar kategori tinggi, dan 7 orang $(20,6 \%)$ yang memiliki minat belajar siswa dalam kategori rendah, dan tidak satu orang siswa pun yang berada pada kategori sangat rendah dan sangat tinggi. Setelah mendapatkan pembelajaran pendekatan CTL dengan soal open ended, tidak terdapat lagi siswa yang minat belajar siswa pada kategori sangat rendah dan rendah. Terlihat ada 4 orang $(11,8 \%)$ yang memiliki minat belajar pada kategori sedang, 22 orang $(64,7)$ pada kategori tinggi, dan 8 orang $(23,5 \%)$ pada kategori sangat tinggi.

Untuk kelas CTL, sebelum diberikan perlakuan sebagian besar siswa memiliki minat belajar pada kategori sedang, yaitu sebanyak 22 orang (71,0\%), memiliki minat belajar yang rendah sebanyak 5 orang $(16,1 \%)$, dan terdapat 4 orang yang memiliki minat belajar siswa rendah yaitu $12,9 \%$. Setelah perlakuan di kelas eksperimen kedua, dengan menggunakan pendekatan CTL, yang memiliki minat belajar kategori sangat tinggi dan sedang masing-masing sebanyak 5 orang $(16,1) \%$, dan yang terbanyak adalah pada kategori tinggi, yaitu 21 orang atau $67,7 \%$, serta tidak ada satupun orang siswa yang berada pada kategori sangat rendah ataupun rendah.

Dari data-data yang ada dan telah di deskripsikan diatas, maka dapat disimpulkan bahwa sebagian besar minat belajar siswa meningkat dari sebelum diberikan pembelajaran dengan pendekatan CTL berada pada kategori sedang, dan setelah diberikan pembelajaran dengan pendekatan CTL baik menggunakan soal open ended maupun tidak minat belajar siswa berada pada kategori tinggi. Hal ini sesuai dengan yang diungkapkan oleh Slameto (2003, p.54), dalam kegiatan pembelajaran hasil dan proses dipengaruhi oleh beberapa faktor, yaitu faktor ekstern dan intern. Salah satu faktor ekstern adalah strategi guru dalam memberikan pembelajaran yang menarik minat siswa. Dalam penelitian salah satu strategi yang digunakan adalah dengan memberikan pembelajaran dengan pendekatan CTL baik dengan memberikan soal open ended maupun tidak. Sehingga dengan diberikannya pembelajaran tersebut, minat belajar siswa baik di kelas CTL dengan soal open ended maupun di kelas CTL terlihat meningkat dari yang awalnya berada pada kategori sedang menjadi sebagian besar siswa berada pada kategori yang tinggi.

\section{Analisis Kemampuan Berpikir Kreatif Mate- matis pada Setiap Aspek}

Selain mengkategorikan tingkat berpikir siswa, data juga dianalisis sesuai dengan indikator kemampuan berpikir kreatif siswa. Siswa 
tersebut berada pada aspek kelancaran, keterperincian, keaslian, atau keluwesan. Setelah mengetahui tingkatan kategori kemampuan berpikir kreatif matematis siswa, pembahasan selanjutnya adalah menentukan berada di aspek kelancaran, keluwesan, keterperincian, atau pada aspek keaslian untuk kemampuan berpikir kreatif matematika siswa SMP Negeri 1 Miri. Hal ini ditujukan agar peneliti selanjutnya sebelum melakukan penelitian dengan menggunakan pendekatan pembelajaran, diharapkan untuk mengetahui terlebih dahulu siswa berada pada aspekaspek yang mana.

Sama seperti pembahasan pada pengkategorian kemampuan berpikir kreatif matematis siswa, untuk mengetahui aspek-aspek kemampuan berpikir kreatif siswa juga menggunakan analisis statitistika deskriptif. Pembahasan aspek kemampuan berpikir kreatif siswa akan dijelaskan berdasarkan hasil analisis dengan menggunakan microssoft excel 2010. Data yang disajikan adalah data frekuensi dan persentase dari hasil perhitungan pada setiap aspek. Sehingga setiap aspek kemampuan berpikir kreatif siswa dapat dkategorikan pada kategori sangat tinggi, tinggi, sedang, rendah, atau sangat rendah.

Untuk kelas eksperimen pertama, yaitu pada kelas CTL dengan soal open ended data yang diperoleh sebelum perlakuan pembelajaran pada aspek kelancaran, untuk kategori tinggi sebesar 32,35\%, kategori sedang 23,53\% dan $44,12 \%$ pada kategori rendah. Aspek keaslian pada kategori rendah $76,47 \%$ dan kategori sangat rendah sebesar 23,53. Untuk aspek keterperincian yaitu $26,47 \%$ berada pada kategori sedang, $64,71 \%$ pada kategori rendah dan $8,82 \%$ berada pada kategori sangat rendah. Aspek keluwesan peesentase tertinggi berada pada kategori rendah, yaitu $73,53 \%$, pada kategori sedang sebesar $8,82 \%$ dan pada kategori sangat rendah sebesar $11,76 \%$. Setelah diberikan pembelajaran pendekatan CTL dengan soal open ended, terlihat terdapat peningkatan presentase kriteria pada semua aspek. Pada aspek kelancaran tidak terdapat lagi jawaban siswa dalam kategori sedang, dan siswa berada pada kategori tinggi dengan $64,71 \%$ dan kategori sangat tinggi sebesar 35,29\%. Pada aspek keaslian terlihat sebelum perlakuan tidak ada satupun jakategori sedang sebesar 32,35 dan masih terdapat jwaban siswa yang berada pada kategori rendah yaitu sebesar $35,29 \%$. Untuk aspek keterperincian, terlihat $2,94 \%$ pada kategori sangat tinggi, 52,94 pada kategori tinggi, 35,29 berada pada kategori sedang dan 8,82\% berada pada kategori rendah. Sedangkan untuk aspek keluwesan, terdapat perbedaan yang mencolok setelah dan sebelum diberi perlakuan yaitu pada kategori rendah, dari $73,53 \%$ menjadi $5,88 \%$, tidak terdapat lagi jawaban siswa yang berada pada kategori sangat rendah. Secara keseluruhan, terlihat bahwa kemampuan berpikir kreatif siswa sebelum perlakuan persentase terbesar berada pada kategori rendah, yaitu 258,82. Setelah diberikan perlakuan dengan pembelajaran menggunakan pendekatan CTL dengan soal open ended, presentase terbesar berada pada kategori tinggi, yaitu sebesar 202,94.

Sementara itu, pada kelas yang diberikan perlakuan dengan pendekatan $C T L$, juga terdapat peningkatan presentase pada semua aspek. Data yang diperoleh sebelum perlakuan pembelajaran pada aspek kelancaran, untuk kategori tinggi sebesar 16,13\%, kategori sedang 48,39\% dan $35,48 \%$ pada kategori rendah. Aspek keaslian pada kategori rendah $61,29 \%$ dan kategori sangat rendah sebesar 38,71. Untuk aspek keterperincian yaitu $9,68 \%$ berada pada kategori sedang, $87,10 \%$ pada kategori rendah dan 3,23\% berada pada kategori sangat rendah. Aspek keluwesan presentase tertinggi berada pada kategori rendah, yaitu $90,32 \%$, pada kategori sedang dan rendah berturut-turut adalah $6,45 \%$ dan $3,23 \%$. Setelah diberikan pembelajaran pendekatan CTL, terlihat terdapat peningkatan presentase kriteria pada semua aspek. Pada aspek kelancaran tidak terdapat lagi jawaban siswa dalam kategori sedang, dan siswa berada pada kategori tinggi dengan $83,87 \%$ dan kategori sangat tinggi sebesar $6,45 \%$. Pada aspek keaslian banyak sekali yang berada pada kategori rendah, yaitu sebesar $70,97 \%$, pada kategori sedang sebesar $22,58 \%$ dan terdapat $6,45 \%$ yang berada pada kategori tinggi. Untuk aspek keterperincian, terlihat $16,13 \%$ pada kategori tinggi, $48,39 \%$ pada kategori sedang dan 35,48\% berada pada kategori rendah. Sedangkan untuk aspek keluwesan, kategori rendah sebesar 51,61\%, kategori sedang sebesar 22,58\% dan pada kategori tinggi sebesar $25,81 \%$. Dengan demikian terlihat bahwa kemampuan berpikir kreatif siswa sebelum perlakuan persentase terbesar berada pada kategori rendah, yaitu 274,18 . Setelah diberikan perlakuan dengan pembelajaran menggunakan pendekatan CTL, presentase terbesar tetap berada pada kategori rendah namun presentasenya mengecil, yaitu menjadi 158,06.

Dengan demikian, dari deskripsi mengenai data tentang kemampuan berpikir kreatif siswa pada setiap aspeknya di atas, dapat diketahui bahwa untuk kelas CTL dengan soal open ended 
pada aspek kelancaran memiliki presentase sebesar $64,71 \%$ pada kategori tinggi, aspek keaslian sebesar 32,35\%, keterperincian dan keluwesan memiliki presentase yang sama yaitu 52,94\%. Sedangkan pada kelas CTL aspek kelancaran memiliki presentase sebesar $83,87 \%$ pada kategori tinggi, aspek keaslian sebesar 6,45\%, keterperincian sebesar $16,13 \%$ dan keluwesan memiliki presentase sebesar $25,81 \%$. Sehingga dapat disimpulkan bahwa siswa kelas VIII SMP Negeri 1 Miri memiliki rata-rata tertinggi kemampuan berpikir kreatif matematis dalam aspek kelancaran. Hal ini sejalan dengan hasil penelitian Azizah (2013), hasil penelitian menunjukkan bahwa dengan diberikan soal open ended, presentase tertinggi kemampuan berpikir kreatif siswa pada indikator aspek berpikir fluency (kelancaran) yaitu sebanyak $57,31 \%$.

\section{Peningkatan Minat Belajar Siswa Berdasar- kan Pendekatan Pembelajaran}

Untuk melihat peningkatan minat belajar matematis siswa dilakukan pengujian pengamatan berpasangan, uji ini dilakukan untuk mengetahui apakah terjadi peningkatan minat belajar siswa setelah diberikan pendekatan contextual teaching and learning dengan soal open ended dan setelah diberikan pendekatan contextual teaching and learning dalam pembelajaran matematika. Uji yang digunakan untuk mengetahui terjadinya peningkatan minat belajar adalah uji $t$ paired terhadap rata-rata skor posttest dengan pretest untuk kedua kelas.

Hasil analisis data dengan menggunakan uji t-paired, menunjukkan bahwa sebelum dilakukan pembelajaran dengan pendekatan CTL dengan soal open ended rata-rata minat belajar matematis siswa sebesar 88,26 dan termasuk pada kategori sedang. Setelah dilakukan pembelajaran terjadi peningkatan rata-rata menjadi 117,44, dan masuk pada kategori tinggi pada kriteria minat belajar matematis siswa. Peningkatan rata-rata sebesar 29,176 dengan signifikansinya 0,000 sehingga $H_{0}$ ditolak, maka dapat disimpulkan bahwa peningkatan minat belajar matematis siswa setelah diberikan pendekatan CTL dengan soal open ended dalam pembelajaran matematika signifikan. Sedangkan untuk kelas CTL, juga terjadi peningkatan rata-rata, namun hanya sebesar 24,853 dari rata-rata 115,38 menjadi 90,53. Namun demikian, dengan melihat taraf signifikansi setelah dilakukan perhitungan yaitu 0,000 , maka $H_{0}$ ditolak, sehingga dapat disimpulkan bawa di kelas ini juga terjadi peningkatan kemampuan berpikir kreatif siswa yang signifikan setelah diberikan pendekatan CTL tanpa menggunakan soal open-ended. Hal ini sejalan dengan penelitian yang dilakukan oleh Setiana \& Jailani (2013) bahwa pembelajaran dengan pendekatan CTL menghasilkan prestasi dan minat belajar siswa yang lebih baik.

\section{Analisis Komparasi Pendekatan Pembela- jaran}

Salah satu dasar pemikiran untuk melakukan penelitian dengan menerapkan suatu pendekatan pembelajaran yang berbeda dari yang sudah diterapkan di SMP N 1 Miri adalah rendahnya kemampuan berpikir kreatif dan kurangnya minat belajar siswa terhadap pembelajaran matematika. Dengan adanya fakta tersebut, maka inovasi perlu dilakukan oleh seorang guru yaitu dengan menerapkan model pembelajaran yang berbeda dari sebelumnya.

Berbagai inovasi pendekatan pembelajaran perlu terus dilakukan untuk meningkatakan mutu pendidikan nasional. Dalam penelitian ini, pendekatan saintifik yang dikombinasikan CTL dengan soal open ended dan CTL dalam pembelajaran matematika akan diselidiki pendekatan mana yang lebih baik ditinjau dari kemampuan berpikir kreatif matematis dan minat belajar siswa materi SPLDV pada kelas VIII E dan VIII F SMP Negeri 1 Miri. Dari hasil data sebelum perlakuan untuk kemampuan berpikir kreatif siswa pada kedua kelompok belum ada yang mencapai kriteria kategori tinggi yang ditetapkan yaitu $19<x \leq 25$. Sedangkan untuk minat belajar matematis siswa rata-rata hanya berada pada kategori sedang untuk kedua kelompok.

Berdasarkan hasil analisis sebelum perlakuan, kedua kelas tidak memiliki perbedaan kemampuan awal ditinjau dari kemampuan berpikir kreatif dan minat belajar matematika siswa. Sedangkan setelah diberikan perlakuan diketahui bahwa terdapat perbedaan yang lebih baik antara pendekatan CTL dengan soal open ended dengan CTL ditinjau dari aspek kemampuan berpikir kreatif dan minat belajar matematika siswa. Hal ini diketahui dari perhitungan uji hipotesis setelah perlakuan yang menunjukkan hasil nilai $F$ sebesar 16,623 dengan signifikansi 0,000. Hasil tersebut menunjukkan adanya perbedaan rata-rata yang diperoleh siswa di masing-masing kelas. Perbedaan ini bisa terjadi karena adanya perbedaan perlakuan yang berupa pendekatan pembelajaran yang digunakan di masing-masing kelas. Akan tetapi aspek mana yang memberikan sumbangan yang signifikan terhadap perbedaan ini 
masih perlu diuji lebih lanjut yaitu dengan uji independent $t$-test.

Berdasarkan hasil uji independent t-test terhadap aspek kemampuan berpikir kreatif siswa diperoleh nilai $t$ sebesar 5,514 dengan keputusan $\mathrm{H}_{0}$ ditolak. Atau dengan kata lain, pendekatan CTL dengan soal open ended lebih baik daripada pendekatan CTL ditinjau dari aspek kemampuan berpikir kreatif siswa. Terdapat kelebihan dari masing-masing pendekatan baik pendekatan CTL dengan soal open ended maupun CTL. Akan tetapi dalam pelaksanaannya pembelajaran dengan pendekatan CTL dengan soal open ended lebih baik daripada pendekatan CTL. Hal ini disebabkan karena pendekatan CTL dengan soal open ended mengaitkan materi pelajaran yang dipelajari siswa dengan situasi dunia nyata dan menggunakan soal yang bersifat terbuka, sehingga mampu mengasah kemampuan yang dimiliki oleh siswa sehingga kemampuan berpikir kreatif siswa lebih baik daripada siswa yang hanya diberikan pendekatan CTL. Siswa akan didorong untuk membuat hubungan antara pengetahuan yang mereka konstruksi sendiri ketika belajar dengan penerapannya dalam kehidupan mereka sehari-hari sehingga terjadi kebermaknaan dalam belajar yang hal ini dapat memudahkan siswa untuk memahami suatu konsep matematika. Hal ini sesuai dengan hasil penelitian Dewey (1916) yang menyimpulkan bahwa siswa akan belajar dengan baik jika apa yang dipelajari terkait dengan apa yang telah diketahui dan terkait juga dengan kegiatan atau peristiwa yang terjadi disekelilingnya. Selain itu, Setiana dan Jailani (2013) dalam penelitiannya menyimpulkan bahwa pembelajaran dengan pendekatan CTL menghasilkan prestasi dan minat belajar siswa yang lebih baik jika dibandingkan dengan pembelajaran dengan pendekatan open ended pada materi peluang siswa kelas IX SMP.

Selanjutnya, untuk aspek minat belajar matematika, pendekatan CTL dengan memberikan soal open ended tidak lebih baik dibandingkan dengan pendekatan CTL. Hal ini terlihat dari nilai $t$ hitung untuk aspek minat belajar matematika siswa adalah sebesar 0,957 dengan kriteria keputusan $\mathrm{H}_{0}$ diterima. Dalam pembelajaran di kelas CTL, siswa lebih mudah memahami konsep yang dipelajarinya karena konsep tersebut terkait dengan konsep dunia nyata mereka sehingga siswa lebih memiliki minat untuk belajar matematika. Hal ini disebabkan karena pendekatan CTL menyajikan pembelajaran dengan mengaitkan materi pelajaran yang dipelajari dengan situasi nyata yang dihadapi siswa dalam kehidupan sehari-hari. Dengan demikian, siswa dapat melihat secara langsung manfaat/ penerapan dari apa yang mereka pelajari, sehingga siswa terdorong untuk mempelajarinya. Sedangkan pendekatan CTL dengan soal open ended kurang menumbuhkan minat belajar siswa dapat dikarenakan beberapa hal, salah satunya seperti pendapat Suherman (2003, p.133) mengenai kelemahan dari pemberian soal-soal open ended yaitu sebagian siswa yang merasa bahwa kegiatan belajar mereka tidak menyenangkan karena kesulitan yang mereka hadapi, sehingga siswa merasa belajar matematika bertambah sulit karena soal-soal yang bersifat terbuka dan memerlukan jawaban yang bervariasi.

\section{SIMPULAN}

Berdasarkan hasil penelitian dan pembahasan, maka diperoleh beberapa kesimpulan, diantaranya: (1) kategori kemampuan berpikir kreatif pada kelas CTL dengan open ended berada pada kategori tinggi, sedangkan pada kelas CTL (tanpa menggunakan soal open-ended) berada pada kategori sedang; (2) kategori minat belajar, siswa di kedua kelas berada pada kategori tinggi; (3) kategori aspek kemampuan berpikir kreatif untuk kedua kelas memiliki presentase tertinggi pada aspek kelancaran; (4) minat belajar siswa untuk kedua kelas meningkat secara signifikan; (5) dan pendekatan CTL menggunakan soal open ended lebih baik daripada pendekatan CTL ditinjau dari aspek kemampuan berpikir kreatif siswa, sedangkan pendekatan CTL menggunakan soal open ended tidak lebih baik daripada pendekatan CTL ditinjau dari minat belajar siswa.

Berdasarkan kesimpulan tersebut, maka beberapa saran yang bisa diperhatikan yaitu: (1) bagi guru matematika SMP yang ingin meningkatkan kemampuan berpikir kreatif dan minat belajar matematika siswa khususnya pada materi SPLDV disarankan agar menerapkan pembelajaran dengan menggunakan pendekatan CTL dan dengan menggunakan soal dalam bentuk open ended; (2) hasil penelitian menunjukkan bahwa masih banyak siswa yang kurang terasah kemampuan berpikir kreatif dalam aspek keaslian dalam mengerjakan soal-soal open ended, hal ini agar menjadi perhatian bagi guru untuk lebih meningkatkan lagi pemahaman konsep dan membimbing siswa untuk lebih giat lagi dalam pembelajaran pada materi tersebut; dan (3) bagi peneliti lain, diharapkan melakukan penelitian 
lanjutan terkait implementasi CTL dengan melibatkan populasi yang lebih luas, sehingga memungkinkan generalisasi yang lebih luas lagi.

\section{DAFTAR PUSTAKA}

Alter, F. (2010). Using the visual arts to harness creativity. The University of Melbourne EJournal, 1(5), 1-14.

Azizah, Y. N. (2013). Pengembangan dan analisis soal tes open-ended problem dalam mengukur keterampilan berpikir kreatif siswa pada materi minyak bumi. Skipsi Sarjana tidak diterbitkan. Bandung: Universitas Pendidikan Indonesia.

Becker, J. P. \& Shimada, S (2005). The openended approach: A new proposal for teaching mathematics. Reston, VA: National Council of Theachers of Mathematics.

Dewey, J. (1916). Democracy and Education: An Introduction to the Philosophy of education. New York, NY: Macmillan Company.

Dwijanto, D. (2007). Pengaruh pembelajaran berbasis masalah berbantuan komputer terhadap pencapaian kemampuan pemecahan masalah dan berpikir kreatif matematik mahasiswa. Disertasi Doctoral tidak diterbitkan. Bandung: Univeritas Pendidikan Indonesia.

Fadilah, A. (2014). Analisis kemampuan berpikir kreatif siswa dalam proses belajar biologi di kelas XI IPA SMA Negeri 5 Kota Jambi. Skripsi Sarjana tidak diterbitkan. Jambi: Universitas Jambi.

Fauzan, A. (2002). Applying mathematics education (RME) in teaching geometry in Indonesia primary schools. Tesis Master tidak diterbitkan. Dutch, Netherland: University of Twente

Gable, R. K. (1986). Instrument development in the affective domain. Boston, MA: Kluwer Publishing.

Hancock, C. L. (1995). Enhancing mathematics learning with open-ended questions. Assessment Standars for School Mathematics, 86(9), 96-99.

Hosnan, M. (2014). Pendekatan saintifik dan kontekstual dalam pembelajaran abad 21. Bogor: Ghalia Indonesia.

Johnson, B., \& Cristensen, L. (2014). Educational research: Quantitative, qualitative, and mixed approaches. ( $3^{\text {rd }} \mathrm{ed}$.). London: SAGE Publications.
Johnson, E., B. (2011). CTL menjadikan kegiatan belajar mengajar mengasyikkan dan bermakna (Terjemahkan A. Chaedar Alwasilah). Thinking strategies for the inquiry classroom. Australia: Education Services Australia.

Kruse, D. (2009). Thinking strategies for the inquiry classroom. Carlton South, Victoria: Australia Curriculum Corporation.

Mahmudi, A. (2010). Mengukur kemampuan berpikir kreatif matematis. Makalah disajikan dalam pada Konferensi Nasional Matematika XV UNIMA Manado.

Meador, K. S. (1997). Creative thinking and problem solving for young learners. Englewood Cliff, NJ: Greenwood Publishing.

Maite, G., \& Laura, B. (2011). Effect of a play program on creative thingking of preschool children. Journal of Psychology, 14(2), 608-618.

Muijs, D. \& Reynolds, D. (2005). Effective teaching, teori \& aplikasi (edisi 2) (Terjemahan Helly Prajitno Soetjipto dan Sri Mulyantini Soetjipto. Yogyakarta: Pustaka Pelajar.

Munandar, U. (2012). Pengembangan kreativitas anak berbakat. Jakarta: Rineka Cipta.

Narendrati, N. (2017). Komparasi pembelajaran statistika melalui pendekatan CTL dan problem posing ditinjau dari prestasi belajar dan minat belajar matematika. Jurnal Riset Pendidikan Matematika, 4(1), 67-77. doi: 10.21831/jrpm.v4i1.12723

Narohita, G. A. (2010). Pengaruh penerapan pendekatan kontekstual terhadap kemampuan pemecahan masalah matematika pada siswa sekolah menengah pertama. JIPP, Edisi Juni, 1436-1449.

Park, H. (2003). The effects of divergent production activities with math inquiry and think aloud of students with math difficulty. Doctoral dissertation, Texas A \& M University. Texas A \& M University.

Pehkonen, E. (2013). The state of art in mathematical creativity. International Reviews on Mathematical Education (ZDM), 29(3), 63-67.

Reynolds, C. R., Livingstone, R. B., \& Willson, V. (2010). Measurement and assessment in 
Pythagoras, 13 (1), 2018 - 75

Puput Wahyu Hidayat, Djamilah Bondan Widjajanti

education. Upper Saddle River, NJ: Pearson Education.

Safari, S. (2005). Belajar dan faktor-faktor yang mempengaruhi. Jakarta: PT. Rineka Cipta.

Setiana, D., \& Jailani, J. (2013). Komparasi metode CTL dan open-ended dengan gaya belajar ditinjau dari prestasi dan minat belajar. PYTHAGORAS: Jurnal Pendidikan Matematika, 8(2), 135-145. doi: 10.21831/pg.v8i2.8939

Singer, K. (1987). Membina hasrat belajar di rumah (Terjemahan Bregman Sitorus). Bandung: Remaja Rosdakarya.

Siswono, T. Y. E (2007). Penjenjangan kemampuan berpikir kreatif dan identifikasi tahap berpikir kreatif siswa dalam memecahkan dan mengajukan masalah matematika. Disertasi Doktor tidak diterbitkan. Surabaya: Universitas Negeri Surabaya.

Slameto, S. (2003). Belajar dan faktor-faktor yang mempengaruhinya. Jakarta: Rineka Cipta.
Stevens, J. P. (2009). Applied multivariate statistics for the social sciences. New York, NY: Taylor and Francis Group.

Suherman, E. (2008). Strategi pembelajaran matematika kontemporer. Bandung: JICA Universitas Pendidikan Indonesia

Syaefudin, U. (2009). Inovasi pendidikan. Bandung: Alfabeta.

Takahashi, A. (2008). Communication as process for students to learn mathematical. Retrieved from http://www.criced. tsukuba.ac.jp/math/apc/apec2008/papers/ PDF/14.Akihiko_Takahashi_USA.pdf. [27 Desember 2013].

Walpole, R. E. (1995). Pengantar statistika. Jakarta: Gramedia Pustaka Utama.

Winkel, W. S. (1996). Psikologi pengajaran. Jakarta: Gramedia.

Zulkarnain, M., Kamariah, M. N., \& Kamaruddin. (2009). Implementation of Contextual System in Mathematics Course. Jurnal. Proceeding of $9^{\text {th }}$ Annual SEAAIR Conference, Malaysia. 